\begin{tabular}{ccc}
\hline International Journal of Engineering \& Technology \\
SPC & Website: www.sciencepubco.com/index.php/IJET \\
Research paper & International Journal of Engineering \&Technology, 8(4) (2019) 559-566 \\
\hline
\end{tabular}

\title{
Multimodal movement planning: logistics network and analysis of transportation alternatives. study case
}

\author{
Miguel Figueroa ${ }^{1 *}$, Otto Mora ${ }^{1}$, Ricardo Fuentes ${ }^{2}$, Alfredo Ojeda ${ }^{3}$ \\ ${ }^{1}$ Department of Civil and Environmental Engineering, Universidad de la Costa, Colombia \\ ${ }^{2}$ Department of Civil and Environmental Engineering, Universidad del Norte, Colombia \\ *Corresponding author E-mail: mfiguero12@cuc.edu.co
}

\begin{abstract}
One of the most relevant problems in transport engineering is the planning of multimodal movements where it is necessary to define the logistics network. To analyze the logistics of a foreign trade operator in Colombia, a mathematical model has been designed for the choice of ports, considering multimodal transport and the state of the art. Initially, a multimodal network was built considering modes of maritime, river, rail and road transport, taking advantage of the main river of Colombia (Magdalena river) and the railway infrastructure. Port operating costs, transshipment, port fees, sea freight, operational and variable costs were included in the analysis. It was found that the most suitable ports in Colombia for export are Cartagena and Buenaventura, with the current infrastructure and demand. It has been found that multimodal arcs are more used than those with a single mode, in addition to exports to Ecuador being made by Buenaventura, while to America and Europe is Cartagena. Additionally, there is sensitivity in the choice of ports concerning the level of prices of road transport since in the Colombian context it is vital to change transfers due to the lack of connectivity between modes such as rail and river.
\end{abstract}

Keywords: Logistics; Multimodal Network; Port Choice; Transport Alternatives

\section{Introduction}

The increasing use of networks where different modes of transport are included has boosted the movement of goods worldwide, generating impacts on the economy and encouraging the development of solutions that seek to solve the problems that revolve around the effective planning of cargo movement [1]. For all the actors of a multimodal system, it is necessary to strategically plan all the decisions that influence the optimization of the resources destined to comply with a certain supply chain. From decisions regarding the location of transshipment terminals at various candidate points to the routes that the merchandise must do to reach its final consumer, they must be managed to look for a minimum cost.

To increase the competitiveness of each nation, recently several investments have been made in infrastructure for various means of transport, seeking to encourage the phenomenon of multimodality. In Colombia, most cargo movements occur through the highway mode and the rail mode used in the transport of coal, one of the main export products in the country [2]. According to information from the Ministry of Transportation [2], in Colombia during 2014 there were approximately 204,855 km of the road network, $854 \mathrm{~km}$ of railways in operation, $24,725 \mathrm{~km}$ of waterways and approximately 543 airport runways. However, due to the poor accessibility that characterizes some modes of transport, it is necessary to implement multimodal movements that facilitate the delivery of the product to its enduser. Additionally, in Colombia there is low connectivity of the multimodal network, in addition to the rail network, it isn't used entirety and is limited to uses such as the Pacific Railroad or private use [3].

To efficiently plan the operations of multimodal movements, it is necessary to propose a logistics network that seeks to minimize operational costs in compliance with the requirements demanded. Thus, in this article a model of choice of ports for the export of cargo of a foreign trade operator is proposed, considering the costs on a multimodal network proposed for Colombia. Due to the high costs of air transport and its convenience to handle products of high value density and long distances, it has been considered that the multimodal network takes advantage of the road, sea, river and rail modes, which in the same way by means of multimodal accompaniment drives savings effects produced by economies of scale. This model seeks to determine which are the national ports that would be used for export and how much cargo each would mobilize, receiving cargo from 16 production plants in different locations in Colombia with 6 international destinations. The use of these ports includes freight and storage handling costs and costs on the road, rail and river multimodal arcs are also included.

The elaboration of port choice models to make strategic decisions in the planning of load movements can be specified from different approaches, considering the maximization of the total benefit, time windows, hub and spoke models, among others. In the literature we can find a vast number of models that consider different limitations and restrictions that have been included to plant the model. Authors like Sitek \& Wikarek [7] minimized the total costs of certain spatial parameters such as the capacity of the transport units, the volume 
occupied by the products, the shipping capacity of the distributor, the duration of the shipment, the distribution service and finally the mode of transport, since it considers multimodality, programming the model LINGO with linear programming.

Other authors like Liansheng \& Jiazhen [4] propose routing models that take into account a simplification of the problem, this simplification consists that everything that goes to the same distribution center shares the same mode of transport, also considers transshipment nodes to enter multimodality, allowing new transport alternatives. Another important consideration is that penalties for early arrival and late arrival are included in your model because they are working with an optimization problem in a determined time window.

Zeng et al [5], propose a model for Chinese automotive logistics, in which while taking into account the entire existing network of the country, storage costs in distribution centers, travel time of cargo and other considerations taken by Liansheng \& Jiazhen [4], they minimize the operational and transportation costs of the production plants and within the arcs of the network. On the other hand, Kazemi \& Szmerekovsky [6] estimate an oil distribution model, in which the maximum capacities of the refineries, distribution centers and the ways in which the product can be sent are assumed, seeking to find the locations attempts to locate distribution centers, calculate their capacities, and the quantities to be sent by primary and secondary modes defined in the network.

\section{Port choice model}

\subsection{Model description}

Due to the different alternatives that the multimodal logistics network allows us to carry out the shipment of cargo from the different sources to the different destinations, a mathematical model has been built allowing to minimize the costs of transport, transshipment, freight, storage, fixed costs of facilities and variable costs also considering the minimization of the costs in the arcs in the network and the fixed costs of using the ports. To integrate multimodal transport, it was decided to simplify the problem and exogenously define arcs that connect all the origin-destination pairs at minimum cost, which are the national trade arcs. These arcs are of national commerce and can be multimodal or highway. The multimodal arcs were built by adding arcs in different ways that will have modal connectivity, such as river, road and rail transport in the national transport network of Colombia. An outline of the problem to be solved by the mathematical model can be visualized in figure 1 considering that each I-J pair in our case has 2 arcs, one road and one multimodal, while each J-K pair has only one maritime arc.

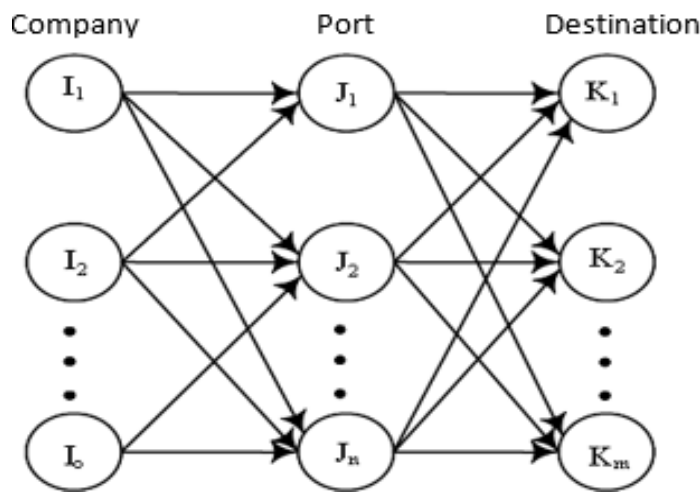

Fig. 1: Simplified General Scheme of the Distribution Model.

Considering the state of the art, a minimization of transport costs and fixed costs of using the ports has been proposed, as the following model shows:

$\mathrm{C}_{\mathrm{ijk}}=\mathrm{D}_{\mathrm{ij}}+\mathrm{Cp}_{\mathrm{j}}+\mathrm{E}_{\mathrm{jk}} \forall \mathrm{i} \in \mathrm{I}, \mathrm{j} \in \mathrm{J}, \mathrm{k} \in \mathrm{K}$

Subject to the following restrictions:

$\mathrm{C}_{\mathrm{ijk}}=\mathrm{D}_{\mathrm{ij}}+\mathrm{Cp}_{\mathrm{j}}+\mathrm{E}_{\mathrm{jk}} \forall \mathrm{i} \in \mathrm{I}, \mathrm{j} \in \mathrm{J}, \mathrm{k} \in \mathrm{K}$

$\sum_{\mathrm{j}=1}^{\mathrm{J}} \mathrm{X}_{\mathrm{ijk}}=1 \forall \mathrm{i} \in \mathrm{I}, \mathrm{k} \in \mathrm{K}$

$\mathrm{X}_{\mathrm{ijk}} \leq \mathrm{P}_{\mathrm{j}} \forall \mathrm{i} \in \mathrm{I}, \mathrm{j} \in \mathrm{J}, \mathrm{k} \in \mathrm{K}$

$\sum_{\mathrm{j}=1}^{J} \sum_{\mathrm{k}=1}^{K} \mathrm{X}_{\mathrm{ijk}} \mathrm{R}_{\mathrm{ik}} \leq \mathrm{Cap}_{\mathrm{i}} \forall \mathrm{i} \in \mathrm{I}$

$\sum_{\mathrm{i}=1}^{\mathrm{I}} \sum_{\mathrm{k}=1}^{\mathrm{K}} \mathrm{X}_{\mathrm{ijk}} \mathrm{R}_{\mathrm{ik}} \leq \mathrm{Cap}_{\mathrm{j}} \forall \mathrm{j} \in \mathrm{J}$

$\mathrm{X}_{\mathrm{ijk}} \mathrm{P}_{\mathrm{j}} \in(0,1) \forall \mathrm{i} \in \mathrm{I}, \mathrm{j} \in \mathrm{J}, \mathrm{k} \in \mathrm{K}$

$\mathrm{Z} \geq 0, \forall \mathrm{i} \in \mathrm{I}, \mathrm{j} \in \mathrm{J}, \mathrm{k} \in \mathrm{K}$

The objective function $(\mathrm{Z})$ indicates a minimization of total transportation costs in a year and is composed of 2 parts. The first part corresponds to a series of summations in IJK, which indicates that the minimum cost arc will be taken between the origin $i$ and the destination 
$\mathrm{k}$ exporting through port $\mathrm{j}(\mathrm{Xijk})$, multiplied by the number of tons to be transported between the pair ik that it is already predetermined (Rik); It is important to mention that Cijk is the minimum cost to transport a ton from origin $\mathrm{i}$ through port $\mathrm{j}$ to destination $\mathrm{k}$ and has been defined exogenously considering a multimodal arc and a road between the ij pairs and a maritime arc between the jk pairs. The second part corresponds to the fixed operating costs of the ports for the use of the ports and includes a binary variable Pj that determines the use of any of the ports.

Equation (1) indicates that Cijk, minimum cost to transport a ton from origin $\mathrm{i}$ through port $\mathrm{j}$ to destination $\mathrm{k}$, must be equal to the cost of transport between origin $\mathrm{i}$ and port $\mathrm{j}$ added to the cost of maritime transport between port $\mathrm{j}$ and the destination $\mathrm{k}$ plus the fixed shipping costs in port $\mathrm{j}$ for cargo, dock and freight handling concepts. The restriction (2) implies that every plant $\mathrm{i}$ will serve exactly 1 port for every customer $\mathrm{k}$, which implies satisfaction of the demand since every plant $\mathrm{i}$ will be obliged to send cargo to at least 1 of the ports, so the load Defendant Rik will be satisfied. According to (3) an origin i will send cargo to a destination k through a port $\mathrm{j}$ if it is being used. The restriction (4) is a restriction of production capacity or product offer, in which the tons sent from any origin i to all destinations $\mathrm{k}$ through all ports $\mathrm{j}$ must be less than or equal to their production capacity, valid for all I. On the other hand, restriction (5) implies that all the tons that arrive at a port $\mathrm{j}$ and that have been sent from all origins to all destinations must be less than or equal to their capacity, for all ports, if It is used. Likewise, the restriction (6) declares the variable of choice of exporting port $\mathrm{Pj}$ as a binary variable as well as the use of the Xijk arc for the realization of the export.

\subsection{Variable definition}

For the description and definition of the model it is important to know the parameters to be considered, the notation to be used and the variables used are presented below:

- I: Origins (companies) defined in Colombia. $i=\{1 \ldots I\}$. the application case considers $I=16$.

- J: Ports for export. $\mathrm{j}=\{1 \ldots \mathrm{J}\}$. The application case considers $\mathrm{J}=4$. Barranquilla, Cartagena, Buenaventura and Santa Marta.

- $\mathrm{K}$ : Node destination abroad according to the zone. $\mathrm{k}=\{1 \ldots \mathrm{K}\}$. the application case considers $\mathrm{K}=7$.

- Z: Annual cost of the operation of the foreign trade operator in pesos (COP).

- $\quad \mathrm{C}_{\mathrm{ijk}}$ : Unit cost in pesos per ton (\$/ ton) of transport from origin $\mathrm{i}$, exporting through port $\mathrm{j}$ to destination $\mathrm{k}$.

- $\quad \mathrm{D}_{\mathrm{ij}}$ : Unit cost in pesos per ton $(\$ /$ ton) of transport from origin $\mathrm{i}$ to port $\mathrm{j}$.

- $\quad E_{\mathrm{jk}}$ : Unit cost in pesos per ton ( $\$ /$ ton) of transport from port $\mathrm{j}$ to destination $\mathrm{k}$.

- Cpj: Average unit operating cost of port $\mathrm{j}$ in pesos per ton exported. Considering dock costs, port use, storage and a real exchange rate of 3069 pesos per dollar (USD).

- $\quad R_{i k}$ : Number of tons demanded in the $K$ destinations of the origins $i$

- Capi: Production capacity of origin i in tons.

- $\quad$ Capj: Port capacity j in tons.

- Decision variables

- The decision variables to be calculated in the model will be which ports will be the ones used to meet the demand, so we must estimate which are the ijk arcs used and more precisely the ports for export. Here are the decision variables:

- $\quad$ Xijk: 1 if sent from the plant $i$ to the destination $\mathrm{k}$ through port $\mathrm{j}, 0$ otherwise.

- $\quad P \mathrm{j}: 1$ if port $\mathrm{j}$ is used, 0 otherwise.

\subsection{Model assumptions}

The port choice model seeks to minimize the total logistics costs associated with the costs of transportation, operation, storage, transshipment, among others. For the operation of the model certain assumptions have been made limiting the problem a bit to the working context of this case. The assumptions have been made to consider certain factors that are dynamic and are not easy to control so that due to availability of information or otherwise due to simplicity of calculation, it has been determined to consider the following:

1) Each origin node $i$ that sends cargo to a destination $\mathrm{k}$, will do it through a single port $\mathrm{j}$.

2) The cargo that reaches a port $\mathrm{j}$ is equal to the load sent from port $\mathrm{j}$, that is, no load is stored.

3) The costs, lengths and travel times remain constant between all pairs of nodes I, J and K during the period analyzed, so there are no changes in the costs of the road or multimodal arcs [14], [16].

4) All cargo is homogeneous so there are no special considerations in cargo handling, all estimates are made with a general type of cargo.

5) The design road vehicle is of type CS according to the denomination of SICETAC [8].

6) The transport of general cargo will be carried out in containers of 21.77 tons of capacity.

7) All containers will have a load equivalent to 20 Ton.

8) Storage and customs processing costs remain constant throughout the year.

9) Ports can receive products from any company and in any quantity. There are no capacity restrictions on the arcs.

\section{Model construction}

The design of the port choice model with a multimodal network implies different requirements that have been considered for the elaboration of this, such as the construction of the logistics network and the evaluation of transport alternatives and facilities necessary for the movement activity of load. For the construction of the multimodal network, the modes of transport currently available in Colombia (road, river, cabotage, and rail) were taken into account, for it sent goods from the origins and to the ports $\mathrm{j}$ so that they are subsequently exported to Ka destinations by sea transport. Within the model, 16 origins were considered, which correspond to the municipalities of Ituango, Turbo, Barranquilla, Bogotá, Cartagena, Gutiérrez, Albania, La Jagua del Pilar, Ciénaga, Ipiales, Cucuta, Pereira, San Andrés, Giron, Buenaventura, and Florida. The ports and candidates for export are those located in the municipalities of Barranquilla, Santa Marta, Cartagena, and Buenaventura. figure 2 shows the geographical locations of cargo sources $i$ (part a) and export ports $j$ (part b) using Google Earth. 


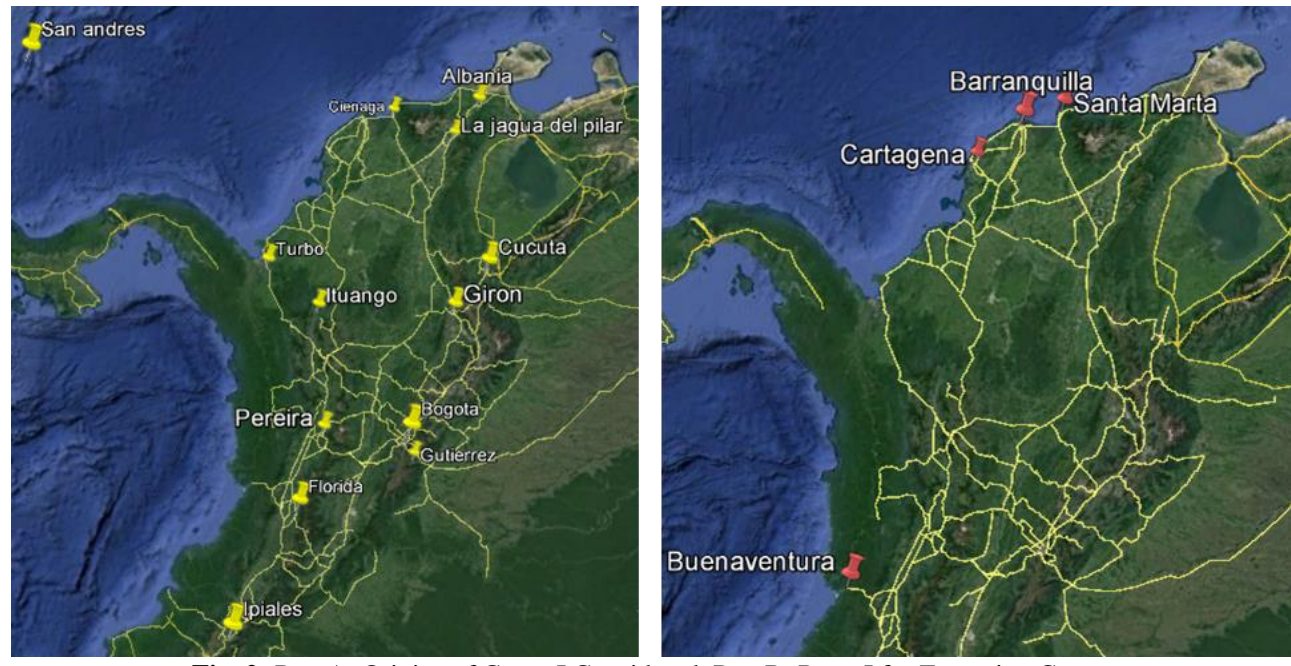

Fig. 2: Part A: Origins of Cargo I Considered. Part B: Ports J for Exporting Cargo.

The export zones have been simplified in a single node for each area, that is, the cargo exported to each zone will be sent to a single port abroad. This simplification was carried out to have a reference point for the calculation of transport costs, sea freight, travel lengths, delays, among others. The destination ports selected for the analysis of export activity correspond to the cities of Montevideo, New York, Guayaquil, Melbourne, Rotterdam, Tokyo, and Venezuela.

It sent cargo from the origins $i$ to the ports $\mathrm{j}$ can be done by road, cabotage or multimodal arcs, so different arcs that connect all nodes $i$ and $\mathrm{j}$ have been raised. Based on the above, it is necessary that every origin node $\mathrm{i}$ has at least one road arc that connects it to all ports $\mathrm{j}$, this arc being the route at minimum estimated cost between the destination origin pair, the length and travel times using the main national road network [9].

To have multimodal arcs, the main road network, the main Magdalena river ports, and the existing rail network are necessary. A multimodal arc will be defined as the sum of the arcs of the different modes that connect a load source $\mathrm{i}$ with a port $\mathrm{j}$. These arcs take into account all the characteristics of the intermodal cargo transshipment nodes in the Magdalena river network and the Valle del Cauca and the Caribbean Coast rail network, such as the current state of the network (active or inactive), capacity loading and unloading, navigable sections of the river, transshipment costs, among others.

The ports located on the Magdalena River chosen to transfer cargo correspond to those of Puerto Boyacá, Puerto Berrio, Barrancabermeja, Puerto Wilches, Gamarra, El Banco, La Dorada, Magangué and Mompox. It is important to mention that the Magdalena River is not navigable in its entirety since it is only navigable from Puerto Berrio to Barranquilla.

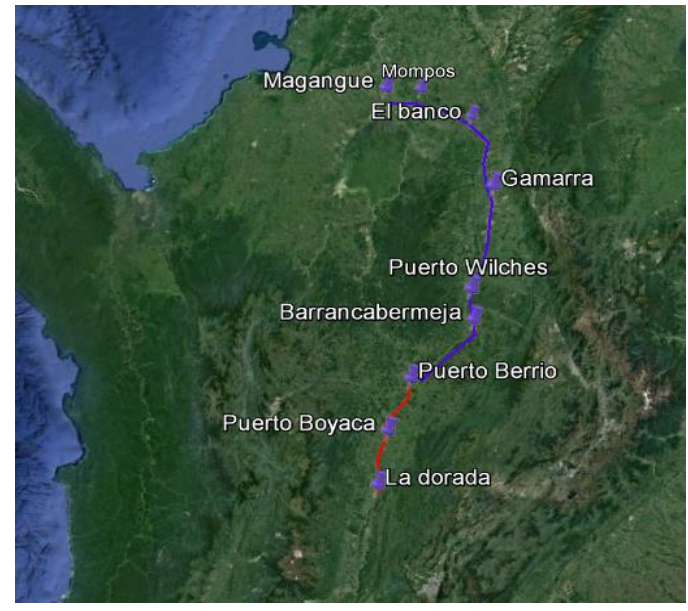

Fig. 3: Ports of the Magdalena River.

The cargo handling capacity of the ports understudy has been estimated from the reports of Procolombia and the Ministry of Transportation. As for the available rail network, only the network that is currently in operation was considered as reported by the Ministry of Transportation and the National Roads Institute (INVIAS). The total costs from each $\mathrm{i}$ to each $\mathrm{j}$ were estimated, considering transport costs, cargo handling, storage, transshipments, port tariffs, and sea freight. These costs have been assigned to each arc of the network defined for the processing of the port choice model. Rates and costs have been estimated according to the designations of the Ministry of Transportation [10], [12], [13], the road cost system [8], [15] and Procolombia simulator for maritime costs [11].

The network was built in QGIS specifying on each arc's characteristics related to travel times, type of arc and total transport costs. There are two types of arcs that connect the origins $i$ with the ports $j$, one of road transport and another multimodal considering the availability of multimodal nodes within the zone of origin i. For multimodal arcs, only those combinations are considered to generate the lowest total transportation costs. The model was estimated using the GAMS software, considering the built network and the established transportation costs, to define the ports to be used for the export of cargo and the minimum routes from each origin $\mathrm{i}$ to a destination $\mathrm{k}$. 

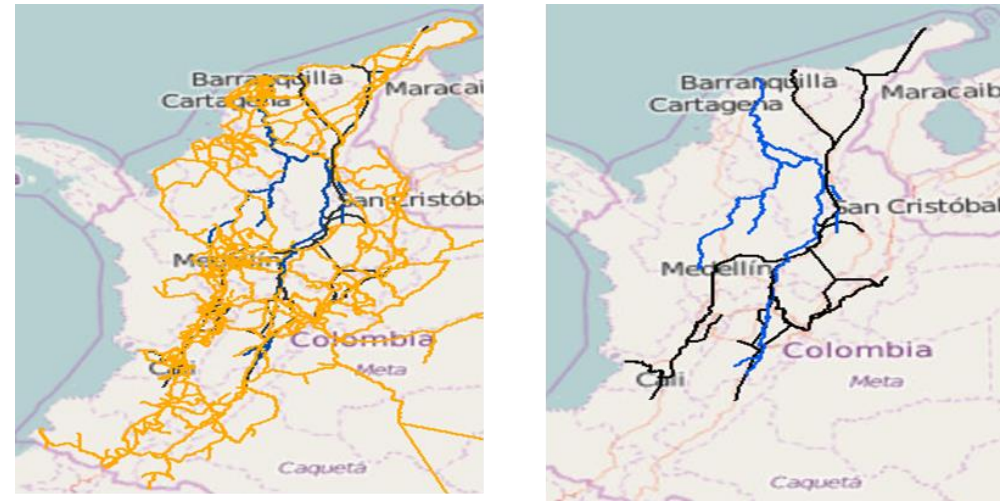

Fig. 4: Part A: Multimodal Network. Part B: Rail and River Network.

\section{Results}

\subsection{Scenario analysis}

For the estimation of the port allocation and choice model, four analysis scenarios were established to observe the sensitivity of the model to changes in demand and costs. The scenarios established for the estimation of the model using the GAMS software are those described in table 1 . With the evaluation of scenarios, it is possible to analyze how cargo transport varies when there are variations within the system, whether due to changes in demand, increased transport costs while taking into account capacity restrictions in ports or even by policies associated with the improvement of transport modes infrastructure such as the river.

Table 1: Simulation Scenarios

\begin{tabular}{ll}
\hline Scenarios & Description \\
\hline Based & Base situation \\
2 & $30 \%$ increase in road transport costs \\
3 & Demand increase by $50 \%$ \\
4 & Improved navigability of river transport \\
\hline
\end{tabular}

\subsubsection{Base scenario}

The results obtained in the simulation of the base scenario presented in tables 2 and 3, show us that the port with the greatest movement of cargo corresponds to that of Cartagena, through which cargo is exported to all destinations k. Additionally, it is noted that for the shipment of cargo to Guayaquil, the most convenient port turns out to be that of Buenaventura, which in turn corresponds to the second port with the greatest movement of cargo due to its proximity to the origins of greater cargo (Bogotá, Ituango, Ipiales and Florida) and due to the availability of rail and river transport modes that allow better use of multimodal transport. Due to the great closeness that exists between the ports of Barranquilla and Santa Marta, the port of Santa Marta does not turn out to be very attractive due to the low differences in terms of variable costs and the marked difference between the fixed costs, being the fixed costs of the port from Barranquilla lower and therefore a much more attractive alternative.

\begin{tabular}{lllll}
\multicolumn{5}{c}{ Table 2: Network Total Cost per Year. Base Situation } \\
\hline Port & Cargo (Ton) & Cost $($ COP) & Fixed Costs (COP) & Total Costs (COP) \\
\hline Barranquilla & 122160 & $\$ 30,578,667,025$ & $\$ 212,323,000$ & $\$ 30,790,990,025$ \\
Cartagena & 276036 & $\$ 60,571,045,561$ & $\$ 243,123,000$ & $\$ 60,814,168,561$ \\
Santa Marta & 0 & 0 & $\$-$ & $\$-$ \\
Buenaventura & 127164 & $\$ 28,138,165,006$ & $\$ 23,231,000$ & $\$ 1,461,396,006$ \\
Totals & 525360 & $\$ 119,287,877,592$ & $\$ 778,677,000$ & \\
\hline
\end{tabular}

Table 3: Used Port for Each Ik Destination. Base Situation

\begin{tabular}{|c|c|c|c|c|c|c|c|}
\hline Origin & Montevideo & Nueva York & Guayaquil & Melbourne & Rotterdam & Tokyo & La Guaira \\
\hline Ituango & 1 & 1 & 4 & 2 & 1 & 1 & 1 \\
\hline \multicolumn{8}{|l|}{ Turbo } \\
\hline Bogota & 1 & 4 & 4 & 2 & 1 & 4 & 1 \\
\hline Gutierrez & & & 4 & 2 & & & \\
\hline Albania & & & & & & & 4 \\
\hline La Jagua del Pilar & & & & & & & 1 \\
\hline Ciénaga & & 1 & 4 & & 1 & 1 & 1 \\
\hline Ipiales & & & 4 & 4 & & 4 & \\
\hline Cucuta & 1 & 1 & 4 & 2 & 2 & 1 & 1 \\
\hline Pereira & & & & 4 & 4 & & \\
\hline \multicolumn{8}{|l|}{ Giron } \\
\hline Buenaventura & 4 & 4 & 4 & 4 & 4 & 4 & 4 \\
\hline Barranquilla & 1 & 1 & 1 & 1 & 1 & 1 & 1 \\
\hline Cartagena & 2 & 2 & 2 & 2 & 2 & 2 & 2 \\
\hline Santa Marta & & & & & & & \\
\hline
\end{tabular}

Note: the number 1 indicates that the port used to export the cargo its Barranquilla, number 2 corresponds Cartagena, number 3 Santa Marta and number 4 Buenaventura. Green indicates that the minimized route to send cargo between ik its Barranquilla, Blue corresponds Cartagena, orange Santa Marta and white Buenaventura. 


\subsubsection{Scenario 1}

By doubling the demand for each pair ik, it is expected that the annual costs of the logistics network will increase, however, the distribution of the load varies concerning the base scenario, with the main result being the use of all ports $\mathrm{j}$ for it sent loading to destinations $\mathrm{k}$. Because variable costs increase due to increased demand and some ports reach their cargo capacity, the port of Santa Marta turns out to be attractive for cargo shipping. Among the results presented in tables 4 and 5, we can highlight that Cartagena works almost to the capacity of the port in annual tons, while Barranquilla handles smaller shipments than in the base situation since the use of the port of Santa Marta deviates most of the cargo that was transported from Barranquilla. It is important to say that most of the merchandise (tons) is sent from the interior of the country from origins such as Bogotá, Ipiales and Buenaventura itself, so Buenaventura should have some advantage due to its geographical proximity; However, since all the demand cannot be satisfied, more merchandise is used to send more merchandise through the arcs that generate the lowest costs, which in turn have as their destination $\mathrm{j}$ the ports corresponding to Barranquilla, Santa Marta and Cartagena, which use economies to scales generated by the implementation of river transport through the Magdalena River at a low cost.

Table 4: Network Total Cost per Year. Scenario 1

\begin{tabular}{lllll}
\hline Port & Cargo (Ton) & Cost (COP) & Fixed Costs (COP) & Total Costs (COP) \\
\hline Barranquilla & 27021 & $\$ 6,326,780,336$ & $\$ 212,323,000$ & $\$ 6,539,103,336$ \\
Cartagena & 532950 & $\$ 118,877,238,641$ & $\$ 243,123,000$ & $\$ 119,120,361,641$ \\
Santa Marta & 109843 & $\$ 27,735,446,131$ & $\$ 332,145,000$ & $\$ 28,067,591,131$ \\
Buenaventura & 159031 & $\$ 35,666,177,866$ & $\$ 323,231,000$ & $\$ 35,989,408,866$ \\
Totals & 828846 & $\$ 188,605,642,974$ & $\$ 1,110,822,000$ & $\$ 189,716,464,974$ \\
\hline
\end{tabular}

Table 5: Used Port for Each Ik Destination. Scenario 1

\begin{tabular}{|c|c|c|c|c|c|c|c|}
\hline Origin & Montevideo & Nueva York & Guayaquil & Melbourne & Rotterdam & Tokyo & La Guaira \\
\hline Ituango & 1 & 1 & 4 & 2 & 1 & 1 & 1 \\
\hline \multicolumn{8}{|l|}{ Turbo } \\
\hline Bogota & 1 & 4 & 4 & 2 & 1 & 4 & 1 \\
\hline Gutierrez & & & 4 & 2 & & & \\
\hline Albania & & & & & & & 3 \\
\hline La Jagua del Pilar & & & & & & & 3 \\
\hline Ciénaga & & 1 & 3 & & 3 & 1 & 3 \\
\hline Ipiales & & & 4 & 4 & & 4 & \\
\hline Cucuta & 1 & 1 & 3 & 2 & 3 & 1 & 3 \\
\hline Pereira & & & & 4 & 4 & & \\
\hline \multicolumn{8}{|l|}{ Giron } \\
\hline Buenaventura & 4 & 4 & 4 & 4 & 4 & 4 & 4 \\
\hline Barranquilla & 1 & 1 & 1 & 2 & 1 & 1 & 1 \\
\hline Cartagena & 2 & 2 & 2 & 2 & 2 & 2 & 2 \\
\hline Santa Marta & & & & & & & \\
\hline
\end{tabular}

\subsubsection{Scenario 2}

One of the most important variables within a logistics network consists of transport costs considering the most significant roads, for this reason, it is important to know the sensitivity of the model to the variation of these costs. The results for this scenario suggest the use of the same ports as in the base situation (Barranquilla, Cartagena and Buenaventura), however, the cargo sent from Buenaventura to destinations $\mathrm{k}$ increases because the transport of merchandise from origins such as Ipiales, Bogotá or Gutierrez end up being more attractive through the iron mode, than using the road mode and then multimodality with the river mode.

\begin{tabular}{lllll}
\multicolumn{5}{c}{ Table 6: Network Total Cost per Year. Scenario 2 } \\
\hline Port & Cargo (Ton) & Cost $($ COP) & Fixed Costs (COP) & Total Costs $($ COP) \\
\hline Barranquilla & 77922 & $\$ 22,272,052,725$ & $\$ 212,323,000$ & $\$ 22,484,375,725$ \\
Cartagena & 275536 & $\$ 60,589,955,851$ & $\$ 243,123,000$ & $\$ 60,833,078,851$ \\
Santa Marta & 0 & 0 & $\$-$ & $\$-$ \\
Buenaventura & 171901 & $\$ 39,843,779,088$ & $\$ 40,167,010,088$ \\
Totals & 525360 & $\$ 122,705,787,665$ & $\$ 77,231,000$ & $\$ 123,484,464,665$ \\
\hline
\end{tabular}

\begin{tabular}{|c|c|c|c|c|c|c|c|}
\hline Origin & Montevideo & Nueva York & Guayaquil & Melbourne & Rotterdam & Tokyo & La Guaira \\
\hline Ituango & 1 & 1 & 4 & 2 & 1 & 1 & 1 \\
\hline \multicolumn{8}{|l|}{ Turbo } \\
\hline Bogota & 1 & 4 & 4 & 2 & 1 & 4 & 1 \\
\hline Gutierrez & & & 4 & 2 & & & \\
\hline Albania & & & & & & & 4 \\
\hline La Jagua del Pilar & & & & & & & 1 \\
\hline Ciénaga & & 1 & 4 & & 1 & 1 & 1 \\
\hline Florida & 4 & 4 & 4 & 4 & 4 & 4 & 4 \\
\hline Cucuta & 1 & 1 & 4 & 2 & 2 & 1 & 1 \\
\hline Pereira & & & & 4 & 4 & & \\
\hline \multicolumn{8}{|l|}{ Giron } \\
\hline Buenaventura & 4 & 4 & 4 & 4 & 4 & 4 & 4 \\
\hline Barranquilla & 1 & 1 & 1 & 1 & 1 & 1 & 1 \\
\hline Cartagena & 2 & 1 & 2 & 2 & 2 & 2 & 2 \\
\hline Santa Marta & & & & & & & \\
\hline
\end{tabular}




\subsubsection{Scenario 3}

One of the main limitations that multimodal transport can have is the optimal conditions of the transport modes infrastructure so that this is possible. Within the logistics network under study, there are sections of the main river network in which it is not possible to carry cargo transportation, for this reason in order to quantify the impact of investments in transport infrastructure within the logistics networks it is decided to simulate the model improving the navigability of the main river network, encouraging the use of multimodality.

The results presented in tables 8 and 9 show that despite the significant improvements that the improvement in navigability implies for the cities or origins of the interior of the country, sent merchandise to the port of Buenaventura is still more attractive due to the availability that has this port with the iron transport of the country. However, the improvements have positioned Barranquilla as a more attractive alternative for him to send merchandise due to having a river arc with direct access to the port and not requiring last-mile highway transshipment. The improvements in navigability allow a cost reduction of about 276 million pesos per year.

Table 8: Network Total Cost per Year. Scenario 3

\begin{tabular}{lllll}
\hline Port & Cargo (Ton) & Cost (COP) & Fixed Costs (COP) & Total Costs (COP) \\
\hline Barranquilla & 123839 & $\$ 30,999,109,560$ & $\$ 212,323,000$ & $\$ 31,211,432,560$ \\
Cartagena & 275536 & $\$ 60,430,610,649$ & $\$ 243,123,000$ & $\$ 60,673,733,649$ \\
Santa Marta & & $\$-$ & $\$-$ & $\$-$ \\
Buenaventura & 125984 & $\$ 27,581,937,803$ & $\$ 323,231,000$ & $\$ 27,905,168,803$ \\
Totals & 525360 & $\$ 119,011,658,013$ & $\$ 778,677,000$ & $\$ 119,790,335,013$ \\
\hline
\end{tabular}

Table 9: Used Port for Each Ik Destination. Scenario 3

\begin{tabular}{|c|c|c|c|c|c|c|c|}
\hline Origin & Montevideo & Nueva York & Guayaquil & Melbourne & Rotterdam & Tokyo & La Guaira \\
\hline Ituango & 1 & 1 & 4 & 2 & 1 & 1 & 1 \\
\hline \multicolumn{8}{|l|}{ Turbo } \\
\hline Bogota & 1 & 4 & 4 & 2 & 1 & 4 & 1 \\
\hline Gutierrez & & & 4 & 2 & & & \\
\hline Albania & & & & & & & 1 \\
\hline La Jagua del Pilar & & & & & & & 1 \\
\hline Ciénaga & & 1 & 3 & & 1 & 1 & 1 \\
\hline Ipiales & & & 4 & 4 & & 4 & \\
\hline Cucuta & 1 & 1 & 1 & 2 & 1 & 1 & 1 \\
\hline Pereira & & & & 4 & 4 & & \\
\hline \multicolumn{8}{|l|}{ Giron } \\
\hline Buenaventura & 4 & 4 & 4 & 4 & 4 & 4 & 4 \\
\hline Barranquilla & 1 & 1 & 1 & 1 & 1 & 1 & 1 \\
\hline Cartagena & 2 & 1 & 2 & 2 & 2 & 2 & 2 \\
\hline Santa Marta & & & & & & & \\
\hline
\end{tabular}

\subsection{Discussion}

Table 10 summarizes the tons sent and the total costs for each port in all the scenarios evaluated. Under normal situations multimodal arches will be much more used than road arcs and that they offer the possibility of exploiting dangerous scale. The origins that would send to Barranquilla would be modified the municipality of Gutierrez and the internal demand of the city, for Cartagena usually domestic demand is supplied, for Santa Marta, Albania, La Jagua del Pilar, Ciénaga and Cucuta, and finally for Buenaventura recently Bogotá, Ituango, Ipiales, Florida and Giron as the main sources of cargo given to geographical proximity. From the main results to highlight, it can be identified that when transport costs are not very different between ports $\mathrm{j}$ (the case when there are two geographically close ports), fixed costs are an important decision variable as long as the conditions are met of capacity and load treatment. Additionally, when road costs increase the distribution of cargo varies because within the logistics networks there will not always be multimodal arcs for some origin pairs and ports $\mathrm{j}$, and the last mile transport always varies through road transport.

Table 10: Resume of Scenarios Results

\begin{tabular}{|c|c|c|c|}
\hline Case & Port & Cargo (Ton) & Total Costs (\$) \\
\hline \multirow{4}{*}{ Base situation } & Barranquilla & 122160 & $\$ 30,790,990,025$ \\
\hline & Cartagena & 276036 & $\$ 60,814,168,561$ \\
\hline & Santa Marta & & $\$-$ \\
\hline & Totals & 525360 & $\$ 120,066,554,592$ \\
\hline \multirow{5}{*}{ Scenario 1} & Barranquilla & 27021 & $\$ 6,539,103,336$ \\
\hline & Cartagena & 532950 & $\$ 119,120,361,641$ \\
\hline & Santa Marta & 109843 & $\$ 28,067,591,131$ \\
\hline & Buenaventura & 159031 & $\$ 35,989,408,866$ \\
\hline & Totals & 828846 & $\$ 189,716,464,974$ \\
\hline \multirow{5}{*}{ Scenario 2} & Barranquilla & 77922 & $\$ 22,484,375,725$ \\
\hline & Cartagena & 275536 & $\$ 60,833,078,851$ \\
\hline & Santa Marta & & $\$-$ \\
\hline & Buenaventura & 171901 & $\$ 40,167,010,088$ \\
\hline & Totals & 525360 & $\$ 123,484,464,665$ \\
\hline \multirow{4}{*}{ Scenario 3} & Barranquilla & 123839 & $\$ 31,211,432,560$ \\
\hline & Cartagena & 275536 & $\$ 60,673,733,649$ \\
\hline & Buenaventura & 125984 & $\$ 27,905,168,803$ \\
\hline & Totals & 525360 & $\$ 119,790,335,013$ \\
\hline
\end{tabular}




\section{Conclusions}

The proposed model considers the fundamental parameters for the choice of port, where fixed and operating costs are of great importance within the model. Operational costs include transport costs derived from the use of the multimodal network, costs for the use of ports and the maritime transport cost corresponding to cargo exports. Within the fixed costs, those administrative costs associated with each of the ports under consideration are considered.

For the choice of port one of the most fundamental parameters corresponding to the cost of the arcs of the internal network in the country, mainly the cost of the road, since the model has been sensitive with respect to this parameter due to the low connectivity of The multimodal network, therefore, relies on road transport to carry out the transport of the last mile, giving priority to parameters such as port capacity and load requirements between the nodes ik. From the total costs, it can be concluded that when the operating costs do not differ much between two geographically close ports, the fixed costs may have a greater weight within the choice of port.

Another important feature is the advantages of geographical positioning, based on the results we can see that Venezuelan, European and American customers specifically their product through the port of Barranquilla, Santa Marta or Cartagena, while Ecuadorians and Asians received from Buenaventura the Most of your cargo. Geographical positioning can also be affected by the availability of transport networks, in this case if the river and rail infrastructure is expanded and improved, transport costs are reduced and those ports with direct access to these modes would have greater use.

\section{References}

[1] G. Liotta, G. Stecca y T. Kaihara, «Optimization of freight flows and sourcing in sustainable production and transportation networks, » Int. J. Production Economics, pp. 351-365, 2015. https://doi.org/10.1016/j.ijpe.2014.12.016.

[2] Ministerio de transporte, «Transporte en cifras. Estadisticas 2014.» Bogotá, $2014 . \quad$ Available online: https://www.mintransporte.gov.co/documentos/15/estadisticas/.

[3] Colprensa, «Los retos del Gobierno en transporte multimodal» 2013. Available online: http://www.vanguardia.com/actualidad/colombia/209954los-retos-del-gobierno-en-transporte-multimodal.

[4] T. Liansheng y H. Jiazhen, «Multimodal Transport Distribution Network Design with Time Window, » Management and Service Science. pp. 1-4, 2011.

[5] T. Zeng, D. Hu y G. Huang, «The Transportation Mode Distribution of Multimodal Transportation in Automotive Logistics, » Social and Behavioral Sciences, pp. 405-417, 2013. https://doi.org/10.1016/j.sbspro.2013.08.048.

[6] Y. Kazemi y J. Szmerekovsky, «Modeling downstream petroleum supply chain: The importance of multi-mode transportation to strategic planning, » Transportation Research, pp. 111-125, 2015. https://doi.org/10.1016/j.tre.2015.09.004.

[7] P. Sitek y J. Wikarek, «Cost optimization of supply chain with multimodal transport » Computer Science and Information Systems, p. 1111-1118, 2012.

[8] SICETAC, «Sistema de información de costos eficientes para el transporte automotor de carga,» 2016. [Online]. Available: http://190.217.54.197:8080/sirtccWeb/costoOperacion.jsf.

[9] Ministerio de transporte, «INVIAS» 2016. Available online: http://www.invias.gov.co/index.php/informacion-institucional/2512-mapa-decarreteras-2014b.

[10] Ministerio de transporte, «Resolución 00289 de 2012» Bogota, Colombia. 2012.

[11] PROCOLOMBIA, «PROCOLOMBIA Exportaciones y turismo,» 2016. Available online: http://www.procolombia.co/node/4374.

[12] Ministerio de transporte, «Diagnostico del transporte,» 2011. Available online: https://www.mintransporte.gov.co/descargar.php?idFile=5608.

[13] PROCOLOMBIA, «Rutas y tarifas del transporte,» 2015. Available online: http://www.colombiatrade.com.co/herramientas/rutas-y-tarifas-detransporte.

[14] J. Gutierrez, «Infraestructura Territorial, Economía y Negocios Internacionales en Colombia» 2009. Available online: http://www.scielo.org.co/scielo.php?script=sci_arttext\&pid=S012046452009000200007\&lng=en\&tlng=en\&refineString=null\&SID=4ALfrTvWkmF6Oys5BKi\&timeSpan=null.

[15] DANE, «Indice de costos del transporte de carga por carretera ICTC» 2016. Available online: http://www.dane.gov.co/index.php/indices-deprecios-y-costos/indice-de-costos-del-transporte-de-carga-por-carretera-ictc. 